Article

\title{
Fast Immobilization of Human Carbonic Anhydrase II on Ni-Based Metal-Organic Framework Nanorods with High Catalytic Performance
}

\author{
Mengzhao Jiao ${ }^{1}$, Jie He ${ }^{1}$, Shanshan Sun ${ }^{1}$, Frank Vriesekoop ${ }^{2}{ }^{\oplus}$, Qipeng Yuan ${ }^{1}$, Yanhui Liu ${ }^{1,3, *}$ \\ and Hao Liang $1, *(\mathbb{D}$ \\ 1 State Key Laboratory of Chemical Resource Engineering, Beijing University of Chemical Technology, \\ Beijing 100029, China; mzjiao@163.com (M.J.); jackhe0616@163.com (J.H.); shanssun@126.com (S.S.); \\ yuanqp@mail.buct.edu.cn (Q.Y.) \\ 2 Department of Food Technology and Innovation, Harper Adams University, Newport TF10 8NB, UK; \\ FVriesekoop@harper-adams.ac.uk \\ 3 Beijing Key Laboratory of Bioprocess, Beijing University of Chemical Technology, Beijing 100029, China \\ * Correspondence: liuyh@mail.buct.edu.cn (Y.L.); lianghao@mail.buct.edu.cn (H.L.); \\ Tel.: +8610-6443-7610 (H.L.)
}

Received: 2 March 2020; Accepted: 15 March 2020; Published: 6 April 2020

\begin{abstract}
Carbonic anhydrase (CA) has received considerable attention for its ability to capture carbon dioxide efficiently. This study reports a simple strategy for immobilizing recombinant carbonic anhydrase II from human (hCA II) on Ni-based MOFs (Ni-BTC) nanorods, which was readily achieved in a one-pot immobilization of His-tagged hCA II (His-hCA II). Consequently, His-hCA II from cell lysate could obtain an activity recovery of $99 \%$ under optimal conditions. After storing for 10 days, the immobilized His-hCA II maintained 40\% activity while the free enzyme lost 91\% activity. Furthermore, during the hydrolysis of p-nitrophenyl acetic acid, immobilized His-hCA II exhibited excellent reusability and still retained more than $65 \%$ of the original activity after eight cycles. In addition, we also found that Ni-BTC had no fixation effect on proteins without histidine-tag. These results show that the Ni-BTC MOFs have a great potential with high efficiency for and specific binding of immobilized enzymes.
\end{abstract}

Keywords: one-pot hydrothermal; immobilizing recombinant; His-hCA II; Ni-BTC nanorods

\section{Introduction}

Carbonic anhydrase (CA, E.C. 4.2.1.1), a zinc metalloenzyme, can efficiently catalyze the reversible hydration of $\mathrm{CO}_{2}$ to bicarbonate ion [1,2]. In nature, chemical fixation of $\mathrm{CO}_{2}$ usually requires high temperatures, high pressure and long reaction times, while carbonic anhydrase can fix carbon dioxide and have a high reaction rate under low pressure conditions [3]. With the intensifying greenhouse effect, the use of carbonic anhydrase is considered as a green and efficient strategy for bio-mineralization of $\mathrm{CO}_{2}$ [4-7]. However, the poor stability and reusability of carbonic anhydrase limits its application in practice [6,8]. Enzyme immobilization on solid supports has been developed to overcome these shortcomings [9-13]. Previous immobilization studies mainly focused on commercial carbonic anhydrase on a wide range of solid supports such as: polyurethane foam [14], SBA-15 [15], mesoporous silica [16], MIL-160 [9] and ZIF-8 [17]. However, high cost and protracted immobilization processes greatly limit the application of immobilized CA [4,10,12].

Fusion protein expression is a common strategy to obtain enzyme proteins. Due to the convenience of purification using Ni-chelating affinity chromatography, histidine tags are widely used for enzyme protein expression $[18,19]$. Nickel ions modified materials for enzyme purification and immobilization 
were developed which are based on the affinity of nickel ions and histidine labels [20-22]. However, until now, there are few piece of research on the one-pot immobilization of $\mathrm{CA}$ via $\mathrm{Ni}^{2+}$ modified materials. The introduction of histidine-tag in CA is more conducive to reducing costs and shortening immobilization time.

Metal-organic frameworks (MOFs) are a new kind of organic-inorganic hybrid porous material $[23,24]$. Since MOF materials are considered to be potent supporting matrices for enzyme immobilization, many kinds of commodity enzymes were immobilized successfully [25-28]. However, other researchers have spent their energy on the design of $\mathrm{Zn}^{2+}, \mathrm{Cu}^{2+}$ or $\mathrm{Fe}^{3+}$-based MOFs for enzyme immobilization [29-31]. Inspired by the specific affinity between $\mathrm{Ni}^{2+}$ and histidine-tags [32], we focus on utilizing Ni-based MOFs to achieve one-pot immobilization of histidine-tagged enzymes. To date, a number of Ni-based MOFs have been reported, however, studies on immobilized enzymes by Ni-based MOFs are rare [33]. Therefore, it is worthwhile to focus on the adsorption characteristics of Ni-based complexes itself.

Herein, the recombinant carbonic anhydrase II from human (hCA II) with His-tag and without His-tag were successfully designed and overexpressed in Escherichia coli (E. coli) (DE3). Meanwhile, Ni-based MOF (Ni-BTC) nanorods were synthesized by employing a one-pot hydrothermal process and were used as immobilization support for CA. Compared to our previous work [34] in this work we were able to carry out the protein immobilization process at room temperature, while achieving very high binding efficiencies. Our approach to realizing His-hCA II one-pot immobilization by Ni-BTC is shown in Figure 1. As a result, the His-tagged hCA II could be efficiently immobilized on Ni-BTC under optimal conditions by a simple mixing step. However, when hCA II (without His-tag) was mixed with Ni-BTC under the same conditions, the hCA II (without His-tag) could not be efficiently immobilized on Ni-BTC. This means that Ni-BTC has specific binding abilities with regards to His-hCA II. Furthermore, a specific protein purification step could be omitted in our application, which could save on production costs in practical applications. In addition, the stability of the free and immobilized His-hCA II under different conditions was also investigated.

\section{Results and Discussion}

\subsection{Synthesis and Characterization of Ni-BTC}

Because of the affinity of $\mathrm{Ni}^{2+}$ and histidine tags, the nickel-modified materials could easily realize the His-tagged enzyme's separation and immobilization in one step. However, most of the previously reported $\mathrm{Ni}^{2+}$ modified materials required complex and lengthy reaction conditions [20,21]. In this work, the light green Ni-based MOF materials were easily obtained and used as support for His-tagged enzyme immobilization.

TEM and SEM were used to characterize the morphology of Ni-BTC. As shown in Figure 1A,B respectively, the as-prepared Ni-BTC were nanorods with an average length of $3 \mu \mathrm{m}$ and an average width was $0.5 \mu \mathrm{m}$. Furthermore, the Ni-BTC had a uniformly smooth long, stick-like structure and it was highly aggregated. Next, the distribution of elements in nanorods was studied by energy dispersive $X$-ray spectral element mapping. The elemental distribution of elements in Figure $1 \mathrm{C}$ was known, and we found that carbon, nitrogen, oxygen and nickel element were distributed homogeneously throughout the Ni-BTC structure. Our results with regard to the structure of synthesized Ni-BTC MOF materials (Figure 1D) appear to be in agreement with those reported elsewhere [35]. These results were also in agreement with our X-ray spectroscopy (XPS) spectrum (Figure S1). Signal peaks of Ni 2p, O 1s, $\mathrm{N} 1 \mathrm{~s}$, and $\mathrm{C} 1 \mathrm{~s}$ were detected, indicating that Ni-BTC was successfully synthesized with nickel acetate and $\mathrm{H}_{3}$ BTC.

The chemical structure of Ni-BTC nanorods had been characterized previously which provided us with knowledge about the linker's integration and the oriented growth of the Ni-BTC nanorods and its cubic geometry [35]. As shown in Figure S2, Ni-BTC nanorods kept stable at temperatures below $100^{\circ} \mathrm{C}$ and showed weight loss $(26.1 \mathrm{wt} \%)$ between $100{ }^{\circ} \mathrm{C}$ and $300^{\circ} \mathrm{C}$, the reason might be the 
vaporization of water and solvent. Significant weight loss (43.1 wt \%) occurred between $300{ }^{\circ} \mathrm{C}$ and $600^{\circ} \mathrm{C}$, which could be assigned to the decomposition of $\mathrm{H}_{3} \mathrm{BTC}$ [34].

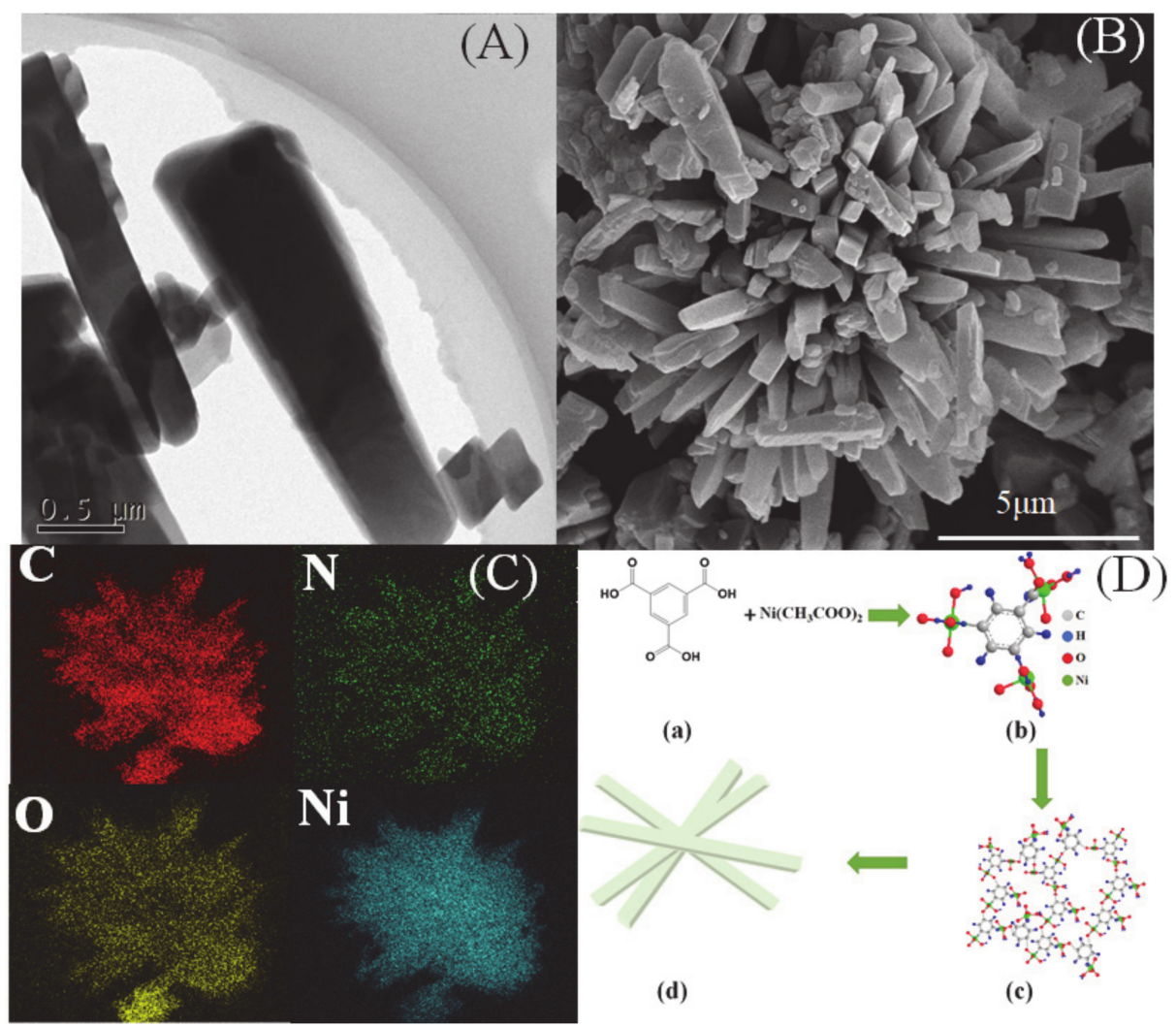

Figure 1. TEM images (A) and SEM images (B) of Ni-BTC and (C) corresponding carbon; nitrogen; oxygen and nickel elemental mapping of Ni-BTC; (D) The synthesis process and structure of the 2D Ni-MOF.

\subsection{Optimal Conditions for His-hCA II Immobilization}

We first prepared the His-hCA II with a histidine-tag in E. coli BL21 (DE3). The plasmid map of pETDuet-1-His-hCA II is shown in Figure S3. Following overexpression in E. coli BL21 (DE3), His-hCA II was extracted in a phosphate buffer $(50 \mathrm{mM}, \mathrm{pH} 7.4)$. The purified His-hCA II appeared as a single band on the silver-stained gels (Figure S4). In order to get the best fixed conditions, $100 \mu \mathrm{L}$ of His-hCA II crude cell lysate was incubated with Ni-BTC under different conditions. The influence of mass ratios on Ni-BTC to crude protein on protein loading and activity recovery of His-hCA II @Ni-BTC were investigated. As shown in Figure 2A, activity recovery of His-hCA II @Ni-BTC increased somewhat from a ratio of 2.5:1 to 5:1 and declined as the ratio increased further. The decline in activity recovery can possibly be attributed to the greater inclusion of heteroproteins from within the crude extract at the higher concentrations adsorbed on the Ni-BTC. Protein loading of His-hCA II @Ni-BTC as the ratio increased from 2.5:1 to 12.5:1 (Figure 2A) increased linearly. The elevated protein loading at a ratio of 12.5:1 also implies the increased adsorption of Ni-BTC on hybrid protein. On the basis of the maximum activity recovery of His-hCA II @Ni-BTC at the ratio of 5:1, we selected this protein loading ratio for further experiments. In addition, we also calculated the amount of immobilized His-hCA II (Table S1), the quality of bounding protein was calculated by the difference between the amount of protein added to the reaction mixture and that in the leachate and washing solutions after immobilization. As a result, the catalytic activity of an immobilized enzyme was 3.1 times that of a free enzyme and the protein yield of crude cell lysate was $31.8 \%$.

The effects of immobilization temperature (Figure 2B) and time (Figure 2C) of Ni-BTC on the loading and activity recovery of His-hCA II @Ni-BTC and crude protein were also investigated. Similar 
to previous reports, $[4,10]$ although the amount of protein binding increased, the activity recovery reached its maximum value at $30^{\circ} \mathrm{C}$ and then decreased with an increase of the temperature from $30^{\circ} \mathrm{C}$ to $50^{\circ} \mathrm{C}$. Human carbonic anhydrase has an optimum temperature close to human body temperature to retain its activity. An increase in the immobilized time showed a near linear increase in the activity recovery of immobilized His-hCA II, increasing from $61.5 \%$ to $88.2 \%$ from 15 to $60 \mathrm{~min}$, and a further increase in activity recovery from 60 to $120 \mathrm{~min}$ to $95 \%$ (Figure 2C). Consequently, an immobilization time of $120 \mathrm{~min}$ was employed for further experiments. Above all, $3 \mathrm{mg}$ Ni-BTC and $100 \mu \mathrm{L}$ cell lysate were mixed with $900 \mu \mathrm{L}$ of phosphates buffer $\left(50 \mathrm{mM}, \mathrm{pH}\right.$ 8.0) for half an hour at $30^{\circ} \mathrm{C}$, then collected by centrifuge for 10 minutes at 12,000 rpm.

We also investigated whether the different monomers in His-hCA II @Ni-BTC could accelerate the relative catalytic activity at equal protein concentrations of His-hCA II @Ni-BTC and His-hCA II. We found that His-hCA II @Ni-BTC and His-hCA II had similar catalytic activity $(p>0.5)$ with an activity recovery of $74.5 \%$ (Figure $2 \mathrm{D}$ ). Whereas $\mathrm{Ni}-\mathrm{BTC}$ and $\mathrm{Ni}^{2+}$ had very low activity recovery $(<10 \%)$ and $\mathrm{H}_{3} \mathrm{BTC}$ had almost no catalytic activity of its own. The reason for the low recovery activity observed for Ni-BTC and $\mathrm{Ni}^{2+}$ might be that the constituent $\mathrm{Ni}^{2+}$ absorbed some of the substrate and presented a minor false positive result. Hence, we conclude that the activity recovery of His-hCA II @Ni-BTC was mainly derived from the His-hCA II enzyme. In addition, we studied the specific binding ability of His-hCA II to Ni-BTC compared to hCA II (not His-tagged). In this experiment, equal quantities of hCA II and His-hCA II were incubated with different amounts of Ni-BTC at $25^{\circ} \mathrm{C}$ for $30 \mathrm{~min}$. The results indicate that the Ni-BTC has a much greater specific binding ability to His-hCA II compared to the non-His-tagged hCA II (Figure 2E).

The activity recovery of immobilized His-hCA II was $98.99 \%$ in optimal conditions, which proved that Ni-BTC could achieve high activity recovery of His-hCA II by a simple one-pot mixing procedure.
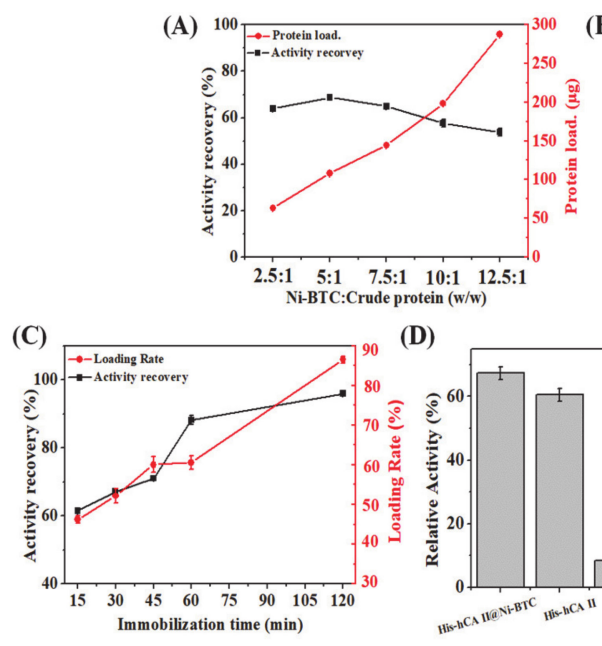

(D)
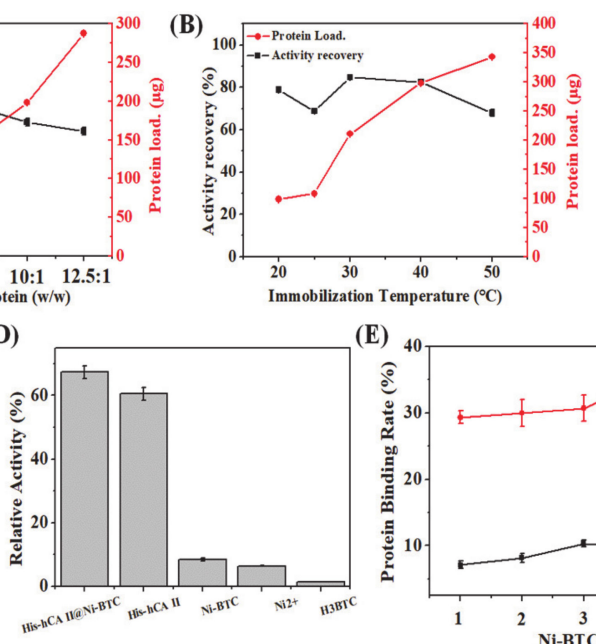

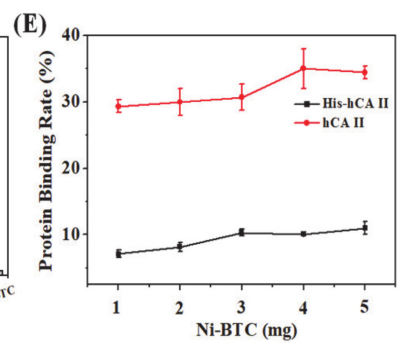

Figure 2. Optimizing immobilization conditions: (A) ratio of the carrier to enzyme; (B) immobilization temperature; (C) immobilization time; (D) the relative catalytic activity of His-hCA II @Ni-BTC, purified His-hCA II, Ni-BTC, $\mathrm{Ni}^{2+}$, H3BTC; (E) the protein binding rate of Ni-BTC to His-hCA II and hCA II.

\subsection{Enzyme (His-hCA II) Stability}

The $\mathrm{pH}$ and thermal stability of the environmental conditions are important for practical application. The stability of free His-hCA II and His-hCA II @Ni-BTC was tested at different pH conditions (phosphate buffer, $50 \mathrm{mM}$, at $30^{\circ} \mathrm{C}$, from $\mathrm{pH} 6$ to 10). After $4 \mathrm{~h}$ of incubation at $\mathrm{pH} 6$, the reaction was performed for $5 \mathrm{~min}$ at room temperature. Free His-hCA II maintained 30.8\% of the original activity ( $\mathrm{pH} 10$ and $30^{\circ} \mathrm{C}$ ), whereas the His-hCA II @Ni-BTC retained 73.7\% of its original activity $\left(\mathrm{pH} 10\right.$ and $30^{\circ} \mathrm{C}$ ) (Figure 3A). Furthermore, the free and His-hCA II @Ni-BTC maintained 59.5\% and $80.7 \%$ of its original activity after incubation at $\mathrm{pH} 7$ for $4 \mathrm{~h}$. These results indicated that His-hCA II $@$ Ni-BTC exhibits better stability than free hCA II under acidic condition, which is in agreement with 
results shown elsewhere [36]. We also tested the effects of different $\mathrm{pH}$ on the shedding of His-hCA II proteins from the Ni-BTC support. The results (Figure S5A) indicate that His-hCA II @Ni-BTC had different degrees of dissociation at different $\mathrm{pH}$ solutions. However, the degree of dissociation (protein shedding) was relatively low and had no effect on the overall catalytic activity, further demonstrating the overall pH stability of His-hCA II @Ni-BTC.
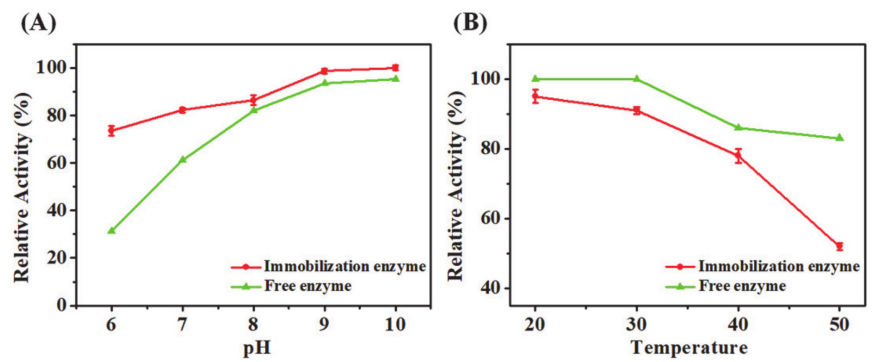

Figure 3. Stability of the immobilized and free His-hCA II (A) at different pHs and (B) temperatures.

The thermal stability of His-hCA II @Ni-BTC compared to with free His-hCA II was investigated, too. The various temperature exposures were carried out at the temperatures indicated, while the actual enzyme assays were performed at $25^{\circ} \mathrm{C}$ in a phosphate buffer $(50 \mathrm{mM}, \mathrm{pH} 8.0)$. The results showed that the relative activities of free enzyme and immobilized enzyme decreased significantly at temperatures over $30^{\circ} \mathrm{C}$ (Figure 3B), with the immobilized enzymes performing worse than the free enzymes. Previous studies also reported a marked loss of immobilized CA activity at these temperature $[4,10]$. Additional experiments were conducted to detect the protein content in His-hCA II @Ni-BTC supernatant following exposure to elevated temperatures $\left(40\right.$ and $\left.50^{\circ} \mathrm{C}\right)$, which showed a $23.7 \%$ and $44.8 \%$ loss of proteins, respectively (Figure S5B). According to the protein shedding rate of His-hCA II @Ni-BTC at different temperatures, Figure 3B shows that the relative activity of His-hCA II @Ni-BTC could reach $82.3 \%$ at $50{ }^{\circ} \mathrm{C}$ while the protein concentration of His-hCA II @Ni-BTC was consistent with free enzyme. It was proved that Ni-BTC has certain supporting and protective effects on enzymes. Allowing for these protein losses as lost immobilized His-hCA II @Ni-BTC, the adjusted residual His-hCA II activity outperformed the free His-hCA II. While this might not explain the exact underpinning reasons as to why the His-hAC II proteins dissociate from the Ni-BTC support, it does explain the lower activity of His-hCA II @Ni-BTC at elevated temperatures might be because the high temperature promoted His-hCA II shedding from His-hCA II @Ni-BTC. However, at the same protein concentration, as shown in Figure S6, the catalytic activity of His-hCA II @Ni-BTC was 2.4 times that of free enzymes after being maintained at $50{ }^{\circ} \mathrm{C}$ for $4 \mathrm{~h}$. Thus, the protective and supporting effect of $\mathrm{Ni}-\mathrm{BTC}$ on the protein under thermal conditions significantly improved the stability of the enzyme.

The storage stability of free and immobilized His-hCA II was also investigated (Figure 4A). At the end of two days of storage in a phosphate buffer $(50 \mathrm{mM}, \mathrm{pH} 8.0)$ at $25^{\circ} \mathrm{C}$, the free enzyme kept $41.8 \%$ of its original activity (i.e., a $58.2 \%$ loss), whereas the immobilized enzyme retained $66.4 \%$ (i.e., a $33.6 \%$ loss) of its original activity. These losses extended further and by the end of 10 days of storage the free enzyme kept $6.4 \%$ of its original activity (i.e., a $93.6 \%$ loss), whereas the immobilized enzyme retained $41.8 \%$ (i.e., a $58.2 \%$ loss) of its original activity after 10 days of storage. During prolonged storage, denaturation and degradation of His-hCA II proteins could significantly reduce enzyme activity. However, the immobilization of His-hCA II on Ni-BTC provided physicochemical stability and mechanical protection, which enabled the His-hCA II to maintain greater stability for long-term reactions compared to free His-hCA II. Finally, the immobilized His-hCA II was tested for recycling. The immobilized His-hCA II was separated by centrifugation after running an experimental standard reaction, after which it was washed three times in water and redispersed in the buffer by vortex mixing before repeating another experimental standard reaction. There was a gradual decrease in the remaining relative enzyme activity at each recycling, however, more than $65 \%$ of original activity remained after eight cycles (Figure 4B). This might be due to the gradual shedding of some 
enzymes from Ni-BTC, and some denaturation during the recovery process. The notion of a gradual release of the enzyme from the Ni-BTC support was confirmed in a subsequent experiment (Figure S7). By determining the protein content in the supernatant from each cycle, we found that each cycle's process was accompanied with protein shedding.

(A)

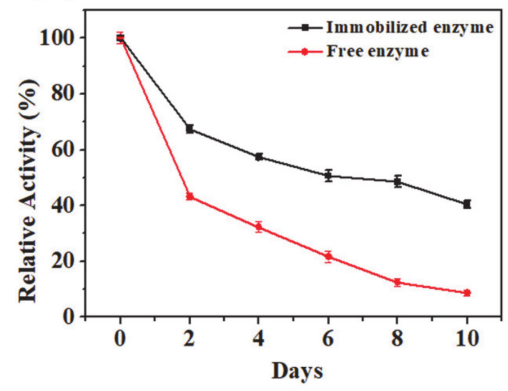

(B)

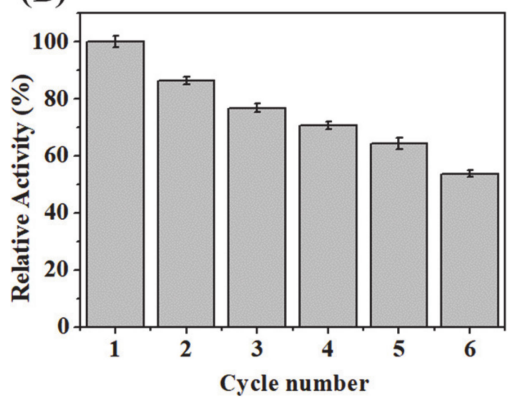

Figure 4. (A) Stability of the immobilized and free His-hCA II of storage stability at $25^{\circ} \mathrm{C}$; (B) reusability of His-hCA II @Ni-BTC.

\subsection{Kinetic Parameters}

To further evaluate the catalytic capacity of immobilized enzymes, we further compared the kinetics of free enzymes and His-hCA II @Ni-BTC. As presented in Table S2, the $\mathrm{K}_{\mathrm{m}}$ and $\mathrm{V}_{\max }$ values for free and His-hCA II @Ni-BTC were determined to be $1.82 \mathrm{mmol} / \mathrm{L}, 1.96 \mathrm{mmol} / \mathrm{L}$ and $0.037 \mathrm{mmol} / \mathrm{min}$, $0.035 \mathrm{mmol} / \mathrm{min}$ for $\mathrm{p}-\mathrm{NPA}$, respectively. The substrates and possible conformational changes of the mass transfer limiting structure play an important role in increasing the $K_{m}$ value of the His-hCA II @Ni-BTC after immobilization.

\section{Materials and Methods}

\subsection{Materials}

Nickel (II) acetate tetrahydrate was purchased from Yuanye Biotechnology Company. (Shanghai, China). Benzene-1, 3, 5-tricarboxylic acid $\left(\mathrm{H}_{3} \mathrm{BTC}\right)$ was purchased from J\&K China Chemical Ltd. p-nitrophenyl acetate (p-NPA) and N, N-dimethylformamide (DMF) were purchased from Aladdin (Shanghai, China). Ampicillin and isopropyl $\beta$-D-1-thiogalactopyranoside (IPTG) were obtained from Beijing QXTD-Biotechnology Co., Ltd. (Beijing, China). Milli-Q water was used to prepare all the buffers and solutions. Bovine serum albumin (BSA) and methionine were purchased from Beijing Chemical Works (Beijing, China). All other reagents and solvents were of analytical grade.

\subsection{Expression and Purification of His-hCA II}

The human carbonic anhydrase (hCA II) gene was cloned to the pETDuet-1 vector with restriction sites BamH I and Kpn I. The recombinant plasmids were transformed into E. coli BL21 (DE3) for protein synthesis. The culture medium was incubated at $37^{\circ} \mathrm{C}$ for $4 \mathrm{~h}$, then isopropyl- $\beta$-Dthiogalactopyranoside (IPTG) was added for induction [37], and the culture continued at $18^{\circ} \mathrm{C}$ for 20 $\mathrm{h}$. The cells were then harvested by high-speed centrifugation $\left(10,000 \mathrm{rpm}, 30 \mathrm{~min}, 4^{\circ} \mathrm{C}\right)$ and lysed by acoustic degradation. Subsequent cell lysate centrifugation $\left(10,000 \mathrm{rpm}, 30 \mathrm{~min}, 4^{\circ} \mathrm{C}\right)$ removed the crude precipitate to obtain the crude protein solution and the protein concentration of the lysate was measured by the Bradford assay using BSA as a standard [38]. The protein fraction was purified with affinity chromatography using a Ni-NTA column (Qiagen) pre-equilibrated with the lysis buffer and eluted with the lysis buffer supplemented with $300 \mathrm{mM}$ of imidazole. The purified protein was analyzed by sodium salt -Polyacrylamide gel electrophoresis (SDS-PAGE). 


\subsection{Preparation of Ni-BTC}

$\mathrm{H}_{3} \mathrm{BTC}(0.5 \mathrm{~g}, 2.38 \mathrm{mmol})$ was dissolved in a DMF/ethanol (V/V = 1:1, $\left.40 \mathrm{~mL}\right)$ mixture and moved to a metal reactor. Then $20 \mathrm{~mL}$ of nickel acetate solution $(1.0725 \mathrm{~g}$, $4.31 \mathrm{mmol})$ was added to the reaction mixture and stirred constantly. Then the reaction was finished after continuous stirring at $70^{\circ} \mathrm{C}$ for $8 \mathrm{~h}$. Finally, the product was separated by centrifugation and washed three times with Milli-Q water and ethanol solution $(95 \%)$, successively.

\subsection{Assay of His-hCA II Immobilization}

\subsubsection{The Immobilization of His-hCA II and Determination of Activity}

The activity of free and His-hCA II @Ni-BTC activity were based on p-NPA with some modifications, as described previously [10]. The $1.5 \mathrm{~mL}$ total reaction volume contained $600 \mu \mathrm{L}$ of phosphate buffer (50 mM, pH 8.0), $300 \mu \mathrm{L}$ Milli-Q water, $500 \mu \mathrm{L}$ freshly prepared p-NPA solution ( $3 \mathrm{mM}$ ) and $100 \mu \mathrm{L}$ crude cell lysate or immobilized enzyme which contained the same protein content of His-hCA II. The mixture was shaken at room temperature for $5 \mathrm{~min}$ and then centrifuged for $10 \mathrm{~min}$ at 12,000 rpm. The increase of absorbance was measured by employing a spectrophotometer (Metash, UV-5100, Shanghai, China) at $348 \mathrm{~nm}$. The same procedure was performed without His-hCA II solution as a control.

To optimize the immobilization conditions, His-hCA II was incubated with Ni-BTC under various conditions. In detail, $100 \mu \mathrm{L}$ cell lysate of His-hCA II (which contained $0.4 \mathrm{mg}$ protein) and $900 \mathrm{~mL}$ Milli-Q water were incubated with Ni-BTC. For optimizing the bonding ratio between enzyme and carrier, $100 \mu \mathrm{L}$ His-hCA II crude cell lysate ( $0.4 \mathrm{mg}$ total protein) was incubated with different amounts of Ni-BTC in a $1 \mathrm{~mL}$ system. For optimization in regard to immobilization temperature, $3 \mathrm{mg} \mathrm{Ni}-\mathrm{BTC}$ was oscillated with $100 \mu \mathrm{L}$ His-hCA II crude cell lysate at different temperatures ranging from $20-50^{\circ} \mathrm{C}$ for $30 \mathrm{~min}$. For optimization in regard to the immobilization time, $3 \mathrm{mg}$ Ni-BTC was incubated with $100 \mu \mathrm{L}$ His-hCA II crude cell lysate at $25^{\circ} \mathrm{C}$ over different lengths of time (15-120 min) with shaking. After separated by centrifugation, the standard curve of protein was determined using Bradford assay with BSA, then analyzed the supernatant and the original protein concentration. The activity of enzyme was detected by the above method. In all experiments, all of the experimental results were measured by three independent experimental groups.

\subsubsection{Enzyme Stability Detection}

For the pH stability, the activity of free His-hCA II and His-hCA II @Ni-BTC was carried out in different phosphate buffer solutions $(50 \mathrm{mM}, \mathrm{pH} 6-10)$ at $25^{\circ} \mathrm{C}$ and the enzymatic activities were determined by the above method. Thermostability was also studied, free enzyme and His-hCA II @Ni-BTC were added to the phosphate buffer $(50 \mathrm{mM}, \mathrm{pH} 8.0)$ over a range of temperatures, $20-50{ }^{\circ} \mathrm{C}$, and incubated for $30 \mathrm{~min}$. For the storage stability, the free enzyme and His-hCA II @Ni-BTC were kept in a phosphate buffer $(50 \mathrm{mM}, \mathrm{pH} 8.0)$ at $25^{\circ} \mathrm{C}$. For the reusability of His-hCA II @Ni-BTC after the reaction, for $5 \mathrm{~min}$, the immobilized enzyme was collected by centrifugation in the next cycle. Then the same substrate and buffer solution were added to the reaction system for the next cycle and the enzyme activity of each cycle was measured by the above method.

\subsubsection{Assay of Kinetics of the His-hCA II}

For the kinetic analysis, the reaction system was detected by the same method as enzyme activity the concentrations of p-NPA were varied from 1.0 to $5.0 \mathrm{mM}$. The $\mathrm{K}_{\mathrm{m}}$ and $\mathrm{V}_{\mathrm{max}}$ were acquired by using a Lineweaver-Burk plot.

$$
\frac{1}{v}=\left(\frac{K m}{V \max } \frac{1}{[S]}\right)+\frac{1}{V \max }
$$




\subsection{Characterization}

Transmission electron microscopy (TEM) analysis was performed on a JEM 1200EX transmission electron microscope (Hitachi, Tokyo, Japan). Scanning electron microscopy (SEM) analysis was performed on a Tecnai G2 F20 scanning electron microscope (FEI, USA). The X-ray diffraction (D8 Advance $X$-ray diffractometer, Bruker, Karlsruhe, Germany) with a $\mathrm{Cu} \mathrm{K} \alpha$ anode $(\lambda=0.15406 \mathrm{~nm})$ at $40 \mathrm{kV}$ and $40 \mathrm{~mA}$ was used to measure the crystal structures of the samples. FTIR spectra were obtained by a FTIR spectrometer (8700/Continuum XL Imaging Microscope, Nicolet, Waltham, MA, USA). The spectra were collected between 400 and $4000 \mathrm{~cm}^{-1}$. X-ray photoelectron spectroscopy (XPS) spectra were recorded on a Thermo Scientific K-Alpha X-ray photoelectron spectrometer. Thermogravimetric analysis (TGA) was performed using a thermogravimetric analyzer (DTG-60A, Shimadzu, Japan) in the range of $30-600{ }^{\circ} \mathrm{C}$ under a nitrogen flow (heating rate of $10^{\circ} \mathrm{C} \mathrm{min}-1$ ).

\section{Conclusions}

In conclusion, a simple and effective single pot immobilization strategy was developed to isolate histidine marker enzymes expressed in E. coli BL21 (DE3). Ni-BTC could be easily compounded by a hydrothermal process and showed the ability to efficiently immobilize the His-hCA II from cell lysate at high load and high activity recovery under optimal conditions. The His-hCA II @Ni-BTC exhibited excellent biocatalytic activity and reusability in the hydrolysis of p-nitrophenyl acetate. All of these results revealed the good potential of His-hCA II @Ni-BTC for biomineralization of $\mathrm{CO}_{2}$.

Supplementary Materials: The following are available online at http://www.mdpi.com/2073-4344/10/4/401/s1, Figure S1: XPS spectra of Ni-BTC nanorods: (a) full scan, (b) Ni 2p, (c) N 1s, Figure S2: TG curves of Ni-BTC, Figure S3: The plasmid map of pETDuet-1-His-hCA II, Figure S4: SDS-PAGE of purified the recombinant hCA II from the culture supernatant. (Lane 1: His6-tagged hCA II purified using Ni-NTA column, Lane 2: supernatant of hCA II cell lysate, Lane 3: molecular weight marker), Figure S5: The protein shedding rate of immobilized enzyme at different $\mathrm{pH}$ and (B) the protein shedding rate of immobilized enzyme at different temperatures, Figure S6: The catalytic activity of His-hCA II@Ni-BTC and free enzyme at the same protein concentration was studied at $40^{\circ} \mathrm{C}$ and $50{ }^{\circ} \mathrm{C}$, Figure S7: The protein shedding rate of cycle process. Table S1: The amount of immobilized His-hCA II, Table S2: Michaelis-Menten kinetics parameters of immobilized and free enzymes.

Author Contributions: Conceptualization, methodology, formal analysis, validation, writing manuscript, and supervision, project management, H.L. Review, F.V. H.L. Experimental work and draft writing, M.J. Other auxiliary work, J.H., S.S., Q.Y., Y.L. All authors have read and agreed to the published version of the manuscript.

Funding: This research received no external funding.

Acknowledgments: This work was supported by the National Natural Science Foundation of China (No. 21606014 and 21878014) and the Double First-rate Program (No. ylkxj03).

Conflicts of Interest: The authors declare no competing financial interests.

\section{References}

1. Kupriyanova, E.; Pronina, N.; Los, D. Carbonic anhydrase-A universal enzyme of the carbon-based life. Photosynthetica 2017, 55, 3-19. [CrossRef]

2. Ren, S.; Feng, Y.; Wen, H.; Li, C.; Sun, B.; Cui, J.; Jia, S. Immobilized carbonic anhydrase on mesoporous cruciate flower-like metal organic framework for promoting $\mathrm{CO}_{2}$ sequestration. Int. J. Biol. Macromol. 2018, 117, 189-198. [CrossRef] [PubMed]

3. Yadav, R.; Joshi, M.; Wanjari, S.; Prabhu, C.; Kotwal, S.; Satyanarayanan, T.; Rayalu, S. Immobilization of carbonic anhydrase on chitosan stabilized Iron nanoparticles for the carbonation reaction. Water Air Soil Pollut. 2012, 223, 5345-5356. [CrossRef]

4. Yadav, R.R.; Mudliar, S.N.; Shekh, A.Y.; Fulke, A.B.; Devi, S.S.; Krishnamurthi, K.; Juwarkar, A.; Chakrabarti, T. Immobilization of carbonic anhydrase in alginate and its influence on transformation of $\mathrm{CO}_{2}$ to calcite. Process Biochem. 2012, 47, 585-590. [CrossRef]

5. Zhang, S.; Du, M.; Shao, P.; Wang, L.; Ye, J.; Chen, J.; Chen, J. Carbonic anhydrase enzyme-MOFs composite with a superior catalytic performance to promote $\mathrm{CO}_{2}$ absorption into tertiary amine solution. Environ. Sci. Technol. 2018, 52, 12708-12716. [CrossRef] 
6. Lee, C.H.; Jang, E.K.; Yeon, Y.J.; Pack, S.P. Stabilization of Bovine Carbonic anhydrase II through rational site-specific immobilization. Biochem. Eng. J. 2018, 138, 29-36. [CrossRef]

7. Wang, S.; Lu, G.Q.M. Effects of promoters on catalytic activity and carbon deposition of $\mathrm{Ni} / \gamma-\mathrm{Al}_{2} \mathrm{O}_{3}$ catalysts in $\mathrm{CO}_{2}$ reforming of $\mathrm{CH}_{4}$. J. Chem. Technol. Biotechnol. 2015, 75, 589-595. [CrossRef]

8. Jin, C.; Zhang, S.; Zhang, Z.; Chen, Y. Mimic carbonic anhydrase using metal-organic frameworks for $\mathrm{CO}_{2}$ capture and conversion. Inorg. Chem. 2018, 57, 2169-2174. [CrossRef]

9. Liu, Q.; Chapman, J.; Huang, A.; Williams, K.C.; Wagner, A.; Garapati, N.; Sierros, K.A.; Dinu, C.Z. User-tailored metal-organic frameworks as supports for carbonic anhydrase. ACS Appl. Mater. Interfaces 2018, 10, 41326-41337. [CrossRef]

10. Al-Dhrub, A.H.A.; Sahin, S.; Ozmen, I.; Tunca, E.; Bulbul, M. Immobilization and characterization of human carbonic anhydrase I on amine functionalized magnetic nanoparticles. Process Biochem. 2017, 57, 95-104. [CrossRef]

11. Wang, D.; Jiang, W. Preparation of chitosan-based nanoparticles for enzyme immobilization. Int. J. Biol. Macromol. 2019, 126, 1125-1132. [CrossRef] [PubMed]

12. Khodarahmi, R.; Yazdanparast, R. Refolding of chemically denatured alpha-amylase in dilution additive mode. Biochim. Biophys. Acta 2004, 1674, 175-181. [CrossRef] [PubMed]

13. Zhang, Y.H.; Chen, K.N.; Zhang, J.N.; Ren, H.; Zhang, X.Y.; Huang, J.H.; Wang, S.Z.; Fang, B.S. Preparation and evaluation of a polymer-metal-enzyme hybrid nanowire forthe immobilization of multiple oxidoreductases. J. Chem. Technol. Biotechnol. 2019, 94. [CrossRef]

14. Ozdemir, E. Biomimetic $\mathrm{CO}_{2}$ sequestration: 1. immobilization of carbonic anhydrase within polyurethane foam. Energy Fuels 2009, 23, 5725-5730. [CrossRef]

15. Vinoba, M.; Kim, D.H.; Lim, K.S.; Jeong, S.K.; Lee, S.W.; Alagar, M. Biomimetic sequestration of $\mathrm{CO}_{2}$ and reformation to $\mathrm{CaCO}_{3}$ using bovine carbonic anhydrase immobilized on SBA-15. Energy Fuels 2011, 25, 438-445. [CrossRef]

16. Fei, X.; Chen, S.; Huang, C.; Liu, D.; Zhang, Y. Immobilization of bovine carbonic anhydrase on glycidoxypropyl-functionalized nanostructured mesoporous silicas for carbonation reaction. J. Mol. Catal. B Enzym. 2015, 116, 134-139. [CrossRef]

17. Liang, H.; Lin, F.F.; Zhang, Z.J.; Liu, B.W.; Jiang, S.H.; Yuan, Q.P.; Liu, J.W. Multicopper laccase mimicking nanozymes with nucleotides as ligands. ACS Appl. Mater. Interfaces 2017, 9, 1352-1360. [CrossRef]

18. Li, Y.; Sun, X.; Feng, Y.; Yuan, Q. Cloning, expression and activity optimization of trehalose synthase from Thermus thermophilus HB27. Chem. Eng. Sci. 2015, 135, 323-329. [CrossRef]

19. Li, Y.; Wang, Z.; Feng, Y.; Yuan, Q. Improving trehalose synthase activity by adding the C-terminal domain of trehalose synthase from Thermus thermophilus. Bioresour. Technol. 2017, 245, 1749-1756. [CrossRef]

20. Vahidi, A.K.; Yang, Y.; Ngo, T.P.N.; Li, Z. Simple and efficient immobilization of extracellular his-tagged enzyme directly from cell culture supernatant as active and recyclable nanobiocatalyst: High-Performance production of biodiesel from waste grease. ACS Catal. 2015, 5, 3157-3161. [CrossRef]

21. Cao, G.; Gao, J.; Zhou, L.; Huang, Z.; He, Y.; Zhu, M.; Jiang, Y. Fabrication of Ni 2+ -nitrilotriacetic acid functionalized magnetic mesoporous silica nanoflowers for one pot purification and immobilization of His-tagged $\omega$-transaminase. Biochem. Eng. J. 2017, 128, 116-125. [CrossRef]

22. Wang, W.; Wang, D.I.; Li, Z. Facile fabrication of recyclable and active nanobiocatalyst: Purification and immobilization of enzyme in one pot with Ni-NTA functionalized magnetic nanoparticle. Chem. Commun. (Camb.) 2011, 47, 8115-8117. [CrossRef] [PubMed]

23. Nadar, S.S.; Rathod, V.K. Facile synthesis of glucoamylase embedded metal-organic frameworks (glucoamylase-MOF) with enhanced stability. Int. J. Biol. Macromol. 2017, 95, 511-519. [CrossRef]

24. Nadar, S.S.; Rathod, V.K. Magnetic-metal organic framework (magnetic-MOF): A novel platform for enzyme immobilization and nanozyme applications. Int. J. Biol. Macromol. 2018, 120, 2293-2302. [CrossRef] [PubMed]

25. Ling, P.; Qian, C.; Gao, F.; Lei, J. Enzyme-immobilized metal-organic framework nanosheets as tandem catalysts for the generation of nitric oxide. Chem. Commun. (Camb.) 2018, 54, 11176-11179. [CrossRef] [PubMed]

26. Chen, W.H.; Luo, G.F.; Vazquez-Gonzalez, M.; Cazelles, R.; Sohn, Y.S.; Nechushtai, R.; Mandel, Y.; Willner, I. Glucose-Responsive metal-organic-framework nanoparticles act as "smart" sense-and-treat carriers. ACS Nano 2018, 12, 7538-7545. [CrossRef] 
27. Shieh, F.K.; Wang, S.C.; Yen, C.I.; Wu, C.C.; Dutta, S.; Chou, L.Y.; Morabito, J.V.; Hu, P.; Hsu, M.H.; $\mathrm{Wu}, \mathrm{K} . \mathrm{C}$; ; et al. Imparting functionality to biocatalysts via embedding enzymes into nanoporous materials by a de novo approach: Size-selective sheltering of catalase in metal-organic framework microcrystals. J. Am. Chem. Soc. 2015, 137, 4276-4279. [CrossRef]

28. Cui, J.; Feng, Y.; Jia, S. Silica encapsulated catalase@metal-organic framework composite: A highly stable and recyclable biocatalyst. Chem. Eng. J. 2018, 351, 506-514. [CrossRef]

29. Samui, A.; Chowdhuri, A.R.; Mahto, T.K.; Sahu, S.K. Fabrication of a magnetic nanoparticle embedded NH2-MIL-88B MOF hybrid for highly efficient covalent immobilization of lipase. RSC Adv. 2016, 6, 66385-66393. [CrossRef]

30. Zhao, M.; Zhang, X.; Deng, C. Rational synthesis of novel recyclable Fe3O4@MOF nanocomposites for enzymatic digestion. Chem. Commun. 2015, 51, 8116-8119. [CrossRef]

31. Govan, J.; Gun'ko, Y.K. Recent advances in the application of magnetic nanoparticles as a support for homogeneous catalysts. Nanomaterials (Basel) 2014, 4, 222-241. [CrossRef] [PubMed]

32. Yu, M.; Liu, D.; Sun, L.; Li, J.; Chen, Q.; Pan, L.; Shang, J.; Zhang, S.; Li, W. Facile fabrication of 3D porous hybrid sphere by co-immobilization of multi-enzyme directly from cell lysates as an efficient and recyclable biocatalyst for asymmetric reduction with coenzyme regeneration in situ. Int. J. Biol. Macromol. 2017, 103, 424-434. [CrossRef] [PubMed]

33. Maniam, P.; Stock, N. Investigation of porous Ni-based metal-organic frameworks containing paddle-wheel type inorganic building units via high-throughput methods. Inorg. Chem. 2011, 50, 5085-5097. [CrossRef] [PubMed]

34. He, J.; Sun, S.; Zhou, Z.; Yuan, Q.; Liu, Y.; Liang, H. Thermostable enzyme-immobilized magnetic responsive Ni-based metal-organic framework nanorods as recyclable biocatalysts for efficient biosynthesis of S-adenosylmethionine. Dalton Trans. 2019, 48, 2077-2085. [CrossRef] [PubMed]

35. Tong, X.; Guo, P.; Liao, S.; Xue, S.; Zhang, H. Nickel-Catalyzed intelligent reductive transformation of the aldehyde group using hydrogen. Green Chem. 2019, 3, 7. [CrossRef]

36. Cao, Y.; Wu, Z.; Wang, T.; Xiao, Y.; Huo, Q.; Liu, Y. Immobilization of Bacillus subtilis lipase on a Cu-BTC based hierarchically porous metal-organic framework material: A biocatalyst for esterification. Dalton Trans. 2016, 45, 6998-7003. [CrossRef]

37. Monnard, F.W.; Nogueira, E.S.; Heinisch, T.; Schirmer, T.; Ward, T.R. Human carbonic anhydrase II as host protein for the creation of artificial metalloenzymes: The asymmetric transfer hydrogenation of imines. Chem. Sci. 2013, 4, 3269-3274. [CrossRef]

38. Bradford, M.M. A rapid method for the quantitation of microgram quantities of protein utilizing the principle of protein-dye binding. Anal. Biochem. 1976, 72, 248-254. [CrossRef] 